\title{
新規乱用薬物の代謝研究
}

\author{
金森達之
}

\section{Study of the Metabolism of New Drugs of Abuse}

\author{
Tatsuyuki Kanamori \\ First Chemistry Section, Third Department of Forensic Science, National Research Institute of \\ Police Science; 6-3-1 Kashiwanoha, Kashiwa, Chiba 277-0882, Japan.
}

(Received July 30, 2018)

\begin{abstract}
Human hepatocytes possess a wider range of phase I and II drug-metabolizing enzyme activities than other liver tissue-derived products, such as human liver microsomes. Thus, hepatocytes may be useful for predicting the in vivo metabolic fate of new drugs of abuse in humans. Recently, new types of human hepatocytes have been made commercially available for use in drug metabolism studies, such as a liver tumor-derived cell line (HepaRG), and a human induced pluripotent stem cell-derived hepatocyte (h-iPS-HEP). In our laboratory, HepaRG has been used to elucidate the metabolic pathways of XLR-11, a synthetic cannabinoid, and its thermal degradant. In addition, the potential of h-iPS-HEP to metabolize drugs was assessed using fentanyl as a model drug, and indeed, h-iPS-HEP exhibited a pattern for fentanyl metabolite formation similar to that observed in vivo. In addition, the phase I and II drug-metabolizing enzyme activities of HepaRG, h-iPS-HEP, liver-humanized mouse-derived hepatocytes (PXB-cellsTM), and human primary hepatocytes were evaluated and compared. HepaRG showed high phase I and II drug metabolism activities; however, the CYP2D6 activity in these cells was quite low, and therefore h-iPS-HEP lacked $O$-methylation and conjugation activities. PXB-cells provided optimal results, i.e., these cells are extremely easy to use, and they possess higher phase I and II drug-metabolizing enzyme activities than the other cells tested. Although PXB-cells are contaminated with mouse-derived cells up to a concentration of several percent, this cell system appears to be promising for the prediction of in vivo human metabolism of new drugs of abuse.
\end{abstract}

Key words_ n new drug of abuse; metabolism; hepatocyte; XLR-11; fentanyl

\section{1.はじめに}

近年，合成カンナビノイド，合成カチノン，フェ ンタニル誘導体などを含有する，いわゆる「危険ド ラッグ」の乱用が広まり，大きな社会問題となって いる。一般に，これらの薬物の摂取を証明するに は，被疑者から採取された資料（尿，血液など）を 分析し，薬物未変化体及び代謝物を検出する必要が ある。しかしながら，新規乱用薬物の代謝様式は不 明な場合が多く，摂取の証明は容易ではない.

そこで, 新規乱用薬物の代謝様式を迅速かつ的確 に予測する実験系の構築が求められている．以前 は，薬物代謝様式を調べるため，ラットなどの小動

科学警察研究所法科学第三部化学第一研究室 (广2770882 千葉県柏市柏の葉 6-3-1)

e-mail: kanamori@nrips.go.jp

本総説は, 日本薬学会第 138 年会シンポジウムS45 で 発表した内容を中心に記述したものである.
物がよく用いられた。ただし，ヒトと小動物では代 謝様式が大きく異なる場合があり（薬物代謝の種 差)，また，近年の動物愛護の機運の高まりもあ り, 薬物代謝研究に実験動物を用いる機会は減少し ている. その一方で, 現在, 薬物代謝研究の主流と なっているのがヒト初代培養肝細胞に代表される各 種ヒト肝細胞やヒト肝ミクロソームなどのヒト組織 由来の試料を用いる手法である。特に，ヒト肝細胞 は, 比較的高価であり, さらに専用の設備が必要と なるものの, 第 I 相, 第 II 相の広範な薬物代謝活性 を有しており，乱用薬物のin vivo 代謝を予測する 目的においては最適のツールと言える。本稿では, 筆者らによるヒト肝細胞を用いた乱用薬物代謝研究 事例について紹介するとともに，近年市販されるよ うになった, 各種ヒト肝細胞の薬物代謝活性を比較 した結果について述べる. 


\section{2. 薬物代謝研究に用いられる肝細胞}

薬物代謝研究に利用可能な肝細胞として, 現在, 様々な製品が入手可能となっている，以下に，筆者 の研究室で使用実績があるものを挙げる。なお，文 中の細胞生存率等の記述は，すべて筆者の実績に基 づくものである.

\section{2-1. ヒト初代培養肝細胞（h-PRM-HEP）}

外科手術などの際にヒトから摘出された肝臓組織 より単離された肝細胞であり，これまで薬物代謝研 究に広く用いられてきた。 日本国内で入手できるの は，ほとんどが海外から輸入される凍結品である. 後述の各細胞に比べ細胞がデリケートであり，解凍 後の細胞生存率が著しく低下する場合がある（70\% 未満).

\section{2-2. ヒト肝腫瘍由来細胞株 HepaRG は,} Hepatocarcinoma 患者の肝腫瘍組織より単離・樹立 された細胞株であり, ${ }^{1)}$ 従来樹立されていた肝細胞 株（HepG2 など）に比べ，高い薬物代謝活性を有 するとされる．樹立されたものは未分化の状態であ り，これを肝細胞の機能を有するまで分化させたも のが市販されている（凍結品．未分化のものも入手 可能であるが，高価であり，また，使用できるプ レート数・使用期間に制限がある)。細胞は極めて 頑健であり，解凍後の細胞生存率は概ね $95 \%$ 以上 である。

2-3. ヒト induced pluripotent stem（iPS）細胞 由来肝細胞（h-iPS-HEP） ヒト iPS 細胞を肝細 胞の機能を有するまで分化させたものであり, ${ }^{2)} い$ くつかの製品(いずれも凍結品)が市販されている. 筆者らは，2 社の製品の計 3 ロットを用いて薬物代 謝活性の評価を行った。いずれの製品も，マルチ ウェルプレートにコーティング処理（Matrigel ${ }^{\mathrm{TM}}$ な ぞ）を行った後，細胞を播種し，培養することが推 奨されている，細胞は頑健であり，いずれの製品・ ロットとも, 解凍後の細胞生存率は $90 \%$ 以上で あった。

2-4. ヒト肝臓キメラマウス由来肝細胞＼cjkstart肝臓 をヒト細胞で置換したマウス（ヒト肝臓キメラマウ ス）より単離された新鮮肝細胞であり, ${ }^{3)}$ 既にマル チウェルプレートに播種されているものを入手可能 である (PXB-cells ${ }^{\mathrm{TM}}$ ，フェニックスバイオ社)。こ の細胞は，解凍・播種の手間がかからず，極めて簡 便に使用できる。

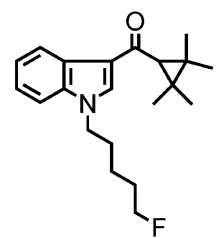

XLR-11

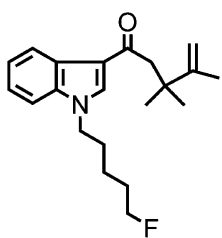

XLR-11-degradant
Fig. 1. Chemical Structures of XLR-11 and XLR-11degradant

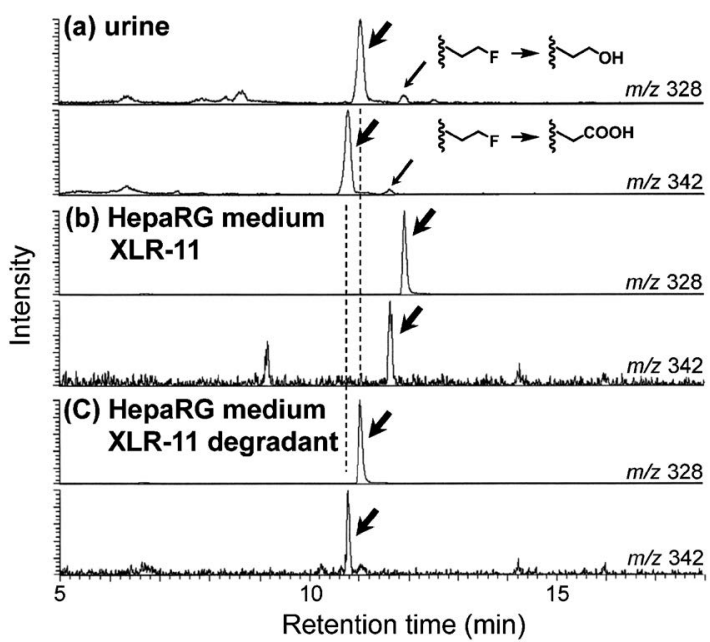

Fig. 2. Extracted Ion Chromatograms Obtained from the Extracts of Urine Sample and Culture Media

(a) Urine sample, (b) culture medium (XLR-11), (c) culture medium (XLR-11-degradant).

\section{3. 肝細胞を用いた薬物代謝研究事例}

3-1. HepaRG による合成カンナビノイド XLR-11 の代謝4)ＸLR-11（Fig. 1）は合成カン ナビノイドの一種であり，乱用が問題となったこと から，2014 年 1 月に麻薬指定された薬物である. 筆者らは，XLR-11 の代謝様式について調べるた め, 所定の手続きを経て XLR-11 使用者の尿試料 を研究用として入手した。 そして，尿試料を分析す るとともに，XLR-11 を添加して培養した HepaRG の培養液の分析も合わせて行い，尿中代謝物と培養 液中代謝物が一致するかを調べた。

Figure 2(a) は尿試料の分析結果で，XLR-11の 2 種の予想代謝物（アルキル鎖末端のアルコール体・ $m / z 328$ 及びカルボン酸体・ $m / z 342)$ をモニター したものである.それぞれのクロマトグラムには, いずれも代謝物と考えられる大きなピークが検出さ れたが，それらのピークの保持時間は，XLR-11を 添加した HepaRG 培養液において検出されたピー 


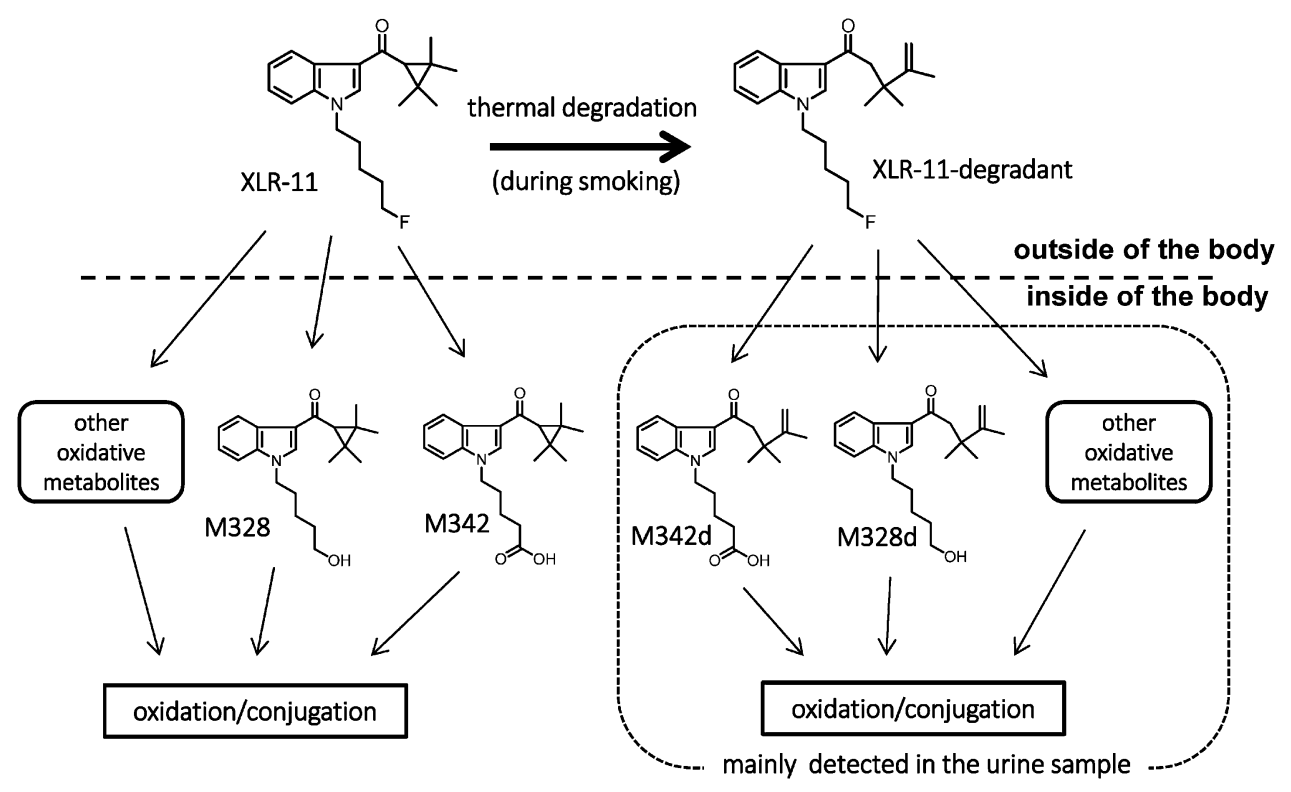

Fig. 3. Behavior of XLR-11 before and after Ingestion

クの保持時間とは異なっていた [Fig. 2(b)].

ところで，類似した構造を有する薬物についての 研究から，XLR-11 が有する三員環構造は，熱によ り開裂して分解生成物（Fig. 1, XLR-11-degradant） を生じることが予想された. ${ }^{5)}$ 合成カンナビノイド は，大麻のように喫煙により摂取される場合も多 く, 摂取時にXLR-11の大部分が熱分解されてい る可能性が浮上した。そこで，XLR-11-degradant （市販品）をHepaRG とともに培養し, 得られた培 養液を分析した。その結果，XLR-11-degradant の HepaRG による代謝物のピーク [Fig. 2(c)］の保 持時間と尿中代謝物の保持時間が一致し，尿中に検 出されたのはXLR-11-degradant の代謝物であるこ とが確認された.

このように, HepaRGを用いた代謝実験により， XLR-11 の摂取から排泄までの挙動（Fig. 3）を明 らかにすることができた.

3-2. h-iPS-HEP による fentanyl の代謝6) hiPS-HEP は，代謝研究に用いるヒト肝細胞を，生 体肝臓に依存せずに供給できるものとして注目され ている. 既に, 複数のメーカーから研究用の h-iPSHEP が市販されている。 このうち, 筆者らは, 夕 カラバイオ社より入手可能な Cellartis ${ }^{\mathrm{TM}}$ 及びリプ

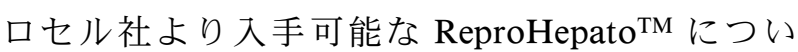
て，薬物代謝能力を評価した。 なお, Cellartis につ いては，ドナーの異なる（すなわち薬物代謝酵素活

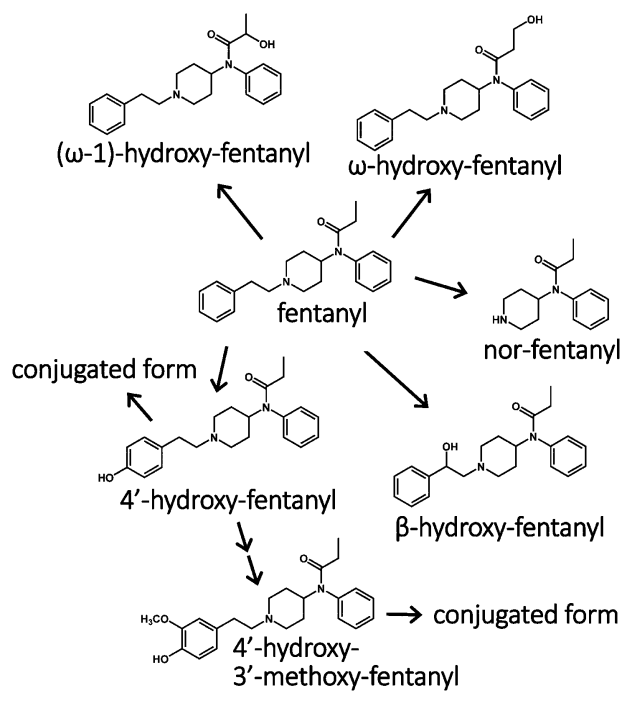

Fig. 4. Metabolic Pathways for Fentanyl

性の異なる）2つのロット（ChiPSC18 及び ChiPSC22）について評価した。評価には，モデル 薬物として，合成オピオイドである fentanyl を用 いた。これまでに明らかになっている fentanyl の 代謝経路を Fig. 4 に示す.

Figure 5 は, fentanyl を各 h-iPS-HEP に添加し て 48 時間培養した後の培養液中の fentanyl 未変化 体の残存量及び各代謝物の生成量を示したものであ る。比較のため, h-PRM-HEP による fentanyl 代 謝デー夕も併せて示す。いずれの細胞の場合も，所 定の培養時間後に fentnyl 未変化体は 60-85\%程度 


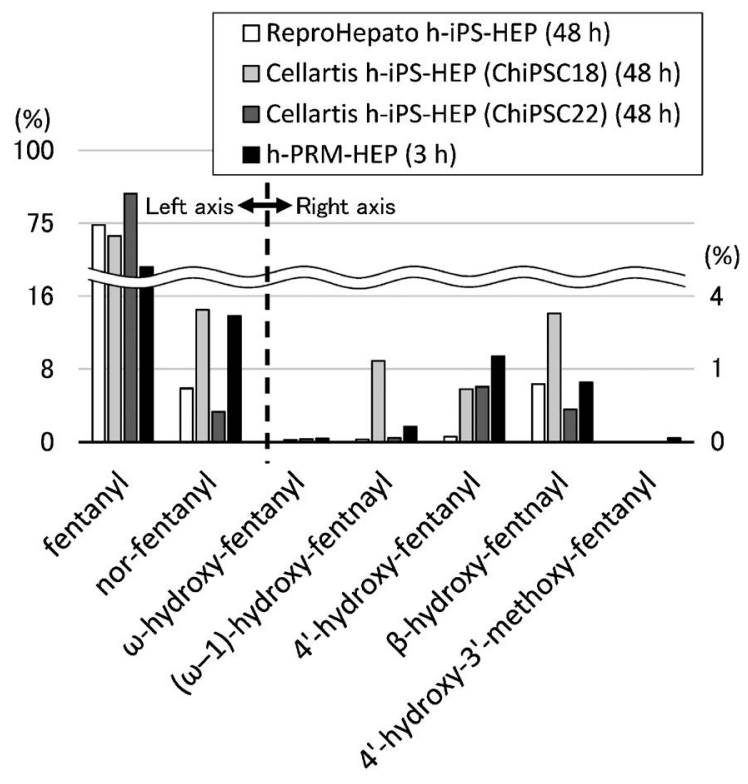

Fig. 5. Metabolite Formation of Fentanyl in h-iPS-HEP and h-PRM-HEP

Each value means the average of duplicate determinations.

残存していた。一方, 主代謝物は脱フェニルエチル 体（nor-fentanyl）であり，そのほかに4'-ヒドロキ シ体， $\beta$-ヒドロキシ体， $(\omega-1)$-ヒドロキシ体等の生 成が認められた。 Fentanyl を摂取したヒト尿中に は, nor-fentanyl が最も多く排泄され（摂取した fentanyl の 8-25\%), ほかに4'-ヒドロキシ体 (3-6\%) や $(\omega-1)$-ヒドロキシ体 $(0-0.05 \%)$ が排泄される との報告があり,7) ヒト iPS 細胞由来肝細胞による fentanyl 代謝パターンは報告されている in vivo の データとよく一致した。

ところで, Cellartis h-iPS-HEP の 2 つのロット のうち, ChiPSC18 については, ChiPSC22 と比較 して CYP3A4 活性が著しく高いとされている(メー カー資料). Figure 5 を見ると, nor-fentanyl, $(\omega-1)$ 一ビロキシ体及び $\beta$-ヒドロキシ体の生成量は, ChiPSC22 に比べ ChiPSC18 の方が圧倒的に多い. これらの代謝物の生成には CYP3A4 が大きく関与 することが筆者らの CYP 反応フェノタイピングに より明らかとなっており, ${ }^{8)}$ 各細胞における薬物代 謝酵素活性が，実際の in vitro 代謝物生成パターン によく反映されることが示された.

一方，h-PRM-HEP では 4'-ヒドロキシ-3'-メトキ シ体がわずかに生成されたが，h-iPS-HEP では， いずれの製品・ロットにおいても，この代謝物は全 く生成されなかった。この代謝物の生成には,
$O$-メチル化酵素（例えばカテコール-O-メチル転移 酵素）が関与していると考えられるが，h-iPS-HEP では，このような酵素が発現していないか，若しく は機能していないことが考えられる.

\section{4. 市販されている各肝細胞の薬物代謝活性の比} 較

現在市販されている各肝細胞の乱用薬物代謝予測 系としての有用性について検証するため，市販の 4 種の肝細胞について, fentanyl をモデル薬物として 代謝物生成パターンを比較した。 Figure 6 は，hPRM-HEP, PXB-cells, h-iPS-HEP (Cellartis hiPS-HEP ChiPSC18） 及び HepaRG による fentanyl 代謝物生成パターンを示したものである (HepaRG については未発表データ. h-PRM-HEP は 3 時間培養，その他の細胞は 48 時間培養)。まず, fentanyl 未変化体残存量に着目すると, h-PRMHEP 及び h-iPS-HEP では，所定の時間培養後に 60-70\%程度残存したのに対し，PXB-cells と HepaRG では残存量は $10 \%$ 以下であり，後者の細 胞が比較的高い薬物代謝活性を有していることが示 唆された。一方，代謝物については，PXB-cells と HepaRG において nor-fentanyl の生成量が極めて多 く，最初に添加した fentanyl の 70-80\%に達したが， h-PRM-HEP 及び h-iPS-HEP では， nor-fentanyl の生成量は 12-14\%に留まった。その他の代謝物と しては，4'-ヒドロキシ体，（ $\omega-1)$-ヒドロキシ体及 び $\beta$-ヒドロキシ体の生成量が比較的多く, 各細胞 での生成量は 0.5-3.5\%程度であった.

前項で述べたように， nor-fentanyl， $(\omega-1)$-ヒド ロキシ体及び $\beta$-ヒドロキシ体の生成にはいずれも CYP3A4 が関与する. PXB-cells と HepaRG では, nor-fentanyl が極めて多く生成し，これらの細胞に おいて CYP3A4 活性が高いことが示唆されたが, これらの細胞による $(\omega-1)$-ヒドロキシ体及び $\beta$-ヒ ドロキシ体の生成量は，他の細胞と比べかならずし も多くなかった。この理由は明らかではないが, 1 つの可能性として, PXB-cells と HepaRG では, $(\omega-1)$-ヒドロキシ体及び $\beta$-ヒドロキシ体がさらに 代謝を受けることが考えられる。

$\omega$-ヒドロキシ体は，いずれの細胞でも生成量は 少なかったが，特に, HepaRG では全く検出でき なかった。構造の類似した別の薬物（butyrylfentanyl）についての研究から， $\omega$-ヒドロキシ体の生 


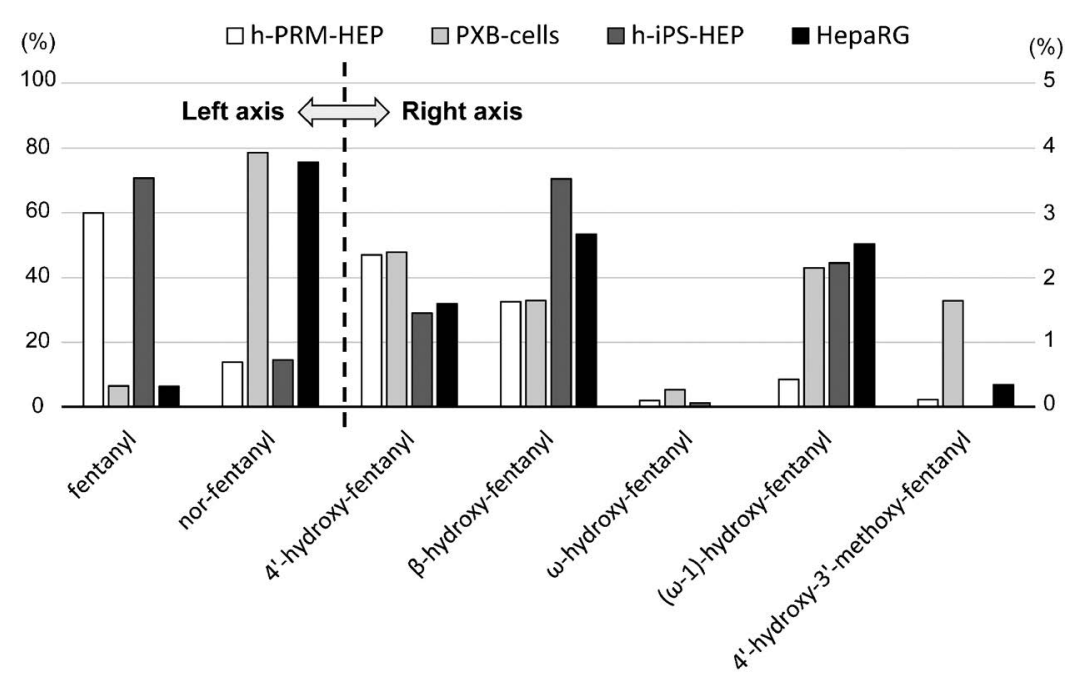

Fig. 6. Metabolite Formation of Fentanyl in h-PRM-HEP, PXB-cells, h-iPS-HEP and HepaRG Each value is the average of duplicate determinations.

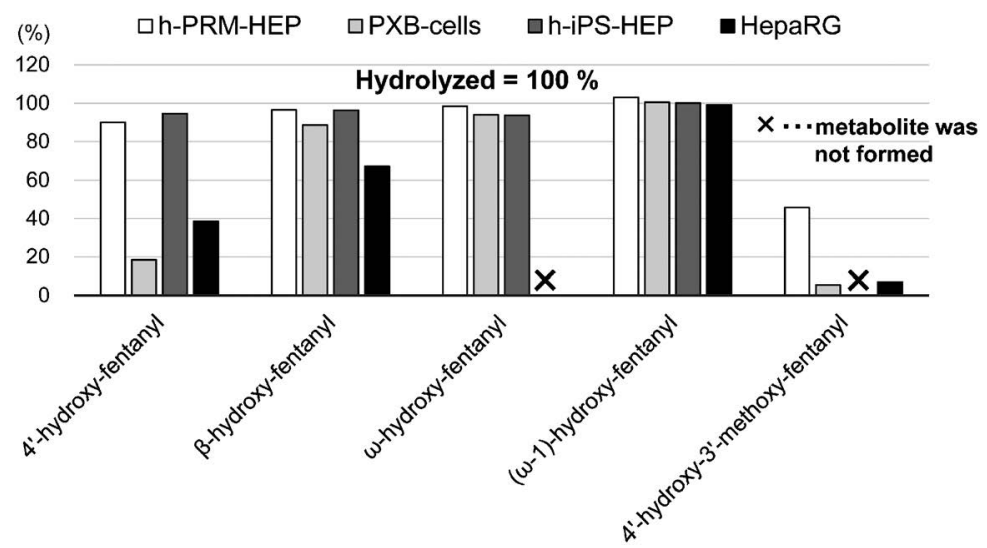

Fig. 7. Effects of Hydrolysis on Amounts of the Metabolites in Culture Media of h-PRM-HEP, PXB-cells, h-iPS-HEP and HepaRG All data are expressed as the means \pm S.E. of quadruplicate measurements.

成には，CYP2D6 の関与が推定される（未発表デー 夕). HepaRG においては, CYP2D6 活性が低いと の報告があり, ${ }^{9)}$ 今回 HepaRG で $\omega$-ヒドロキシ体 が生成しなかったのは，この細胞における低い CYP2D6 活性によるかもしれない。一方, h-iPSHEP では，4'-ヒドロキシ-3'-メトキシ体が全く生 成せず，O-メチル化活性が欠如していると考えら れた.

さらに, 各細胞の第 II 相反応（グルクロン酸若 しくは硫酸抱合）の活性について検証するため, fentanyl を添加した各細胞の培養液について, 加水 分解処理を行う場合と行わない場合のそれぞれにつ いて分析し，各代謝物の量を比較した結果を Fig. 7 に示す（未発表デー夕。h-PRM-HEP は 3 時間培 養, その他の細胞は 48 時間培養)。 PXB-cells と
HepaRG では，加水分解処理をスキップすると 4'-ヒドロキシ体及び 4'-ヒドロキシ-3'-メトキシ体 の検出量が大きく減少したことから，これらの代謝 物の多くがグルクロン酸若しくは硫酸により抱合さ れていると考えられた。一方, h-PRM-HEP とhiPS-HEP では，4'-ヒドロキシ体の量は, 加水分解 処理の有無にあまり影響されなかつたことから，ほ とんど抱合されていないと考えられた，以上の結果 から, 今回評価した 4 種の細胞の抱合活性について,

PXB-cells と HepaRG は強く, h-PRM-HEP と hiPS-HEP は弱いと判断された。なお， $(\omega-1)$-ヒド ロキシ体については，いずれの細胞においても，加 水分解処理の有無による定量值の差異がほとんど認 められなかったことから，この代謝物は，極めて抱 合を受け難いと考えられた。 


\section{5. おわりに}

ヒト肝細胞は，肝ミクロソームなどの肝臟組織由 来の試料に比へ，第 I 相・第 II 相の広範な薬物代 謝酵素活性を有しており，乱用薬物のヒト in vivo での代謝を予測する上で極めて有用なツールであ る。近年，様々な新しいタイプのヒト肝細胞が利用 可能となっており，薬物代謝研究における活用が期 待されている．筆者らの研究室の評価では，いずれ の細胞（h-PRM-HEP，HepaRG，h-iPS-HEP 及び PXB-cells）も薬物代謝研究における有用性が示唆 されたが，HepaRG では，CYP2D6による代謝反 応をうまく再現できない可能性があること, h-iPSHEP では，O-メチル化反応や第 II 相反応が確認で きない，といった問題点が認められた。 PXB-cells については，第 I 相・第 II 相の薬物代謝活性の高 さ，扱い易さにおいて非常に優れていると考えられ た. しかしながら，代謝パターンに大きな影響は与 えないと考えられているものの，PXB-cells には 数\%のマウス細胞が混入していることに留意する必 要がある. ${ }^{10)}$ 将来は, 現行の細胞が改良されるか,

あるいは，新規に細胞が開発されることで，より扱 い易く，ヒト in vivoに近い代謝パターンを与える ヒト肝細胞が提供され，新規乱用薬物代謝研究が一 層発展することが期待される.

謝辞本研究は, 科学研究費補助金 (JSPS15K08895）の助成を受けたものです。深く感謝申 し上げます。

利益相反＼cjkstart開示すべき利益相反はない.

\section{REFERENCES}

1) Gripon P., Rumin S., Urban S., Le Seyec J.,
Glaise D., Cannie I., Guyomard C., Lucas J., Trepo C., Guguen-Guillouzo C., Proc. Natl. Acad. Sci. USA, 99, 15655-15660 (2002).

2) Takayama K., Morisaki Y., Kuno S., Nagamoto Y., Harada K., Furukawa N., Ohtaka M., Nishimura K., Imagawa K., Sakurai F., Tachibana M., Sumazaki R., Noguchi E., Nakanishi M., Hirata K., Kawabata K., Mizuguchi H., Proc. Natl. Acad. Sci. USA, 111, 16772-16777 (2014) .

3) Ishida Y., Yamasaki C., Tateno C., Saibou, 45, 338-341 (2013).

4) Kanamori T., Kanda K., Yamamuro T., Kuwayama K., Tsujikawa K., Togawa Iwata Y., Inoue H., Drug Test. Anal., 7, 341-345 (2015)

5) Adamowicz P., Zuba D., Sekuła K., Forensic Sci. Int., 233, 320-327 (2013).

6) Kanamori T., Togawa Iwata Y., Segawa H., Yamamuro T., Kuwayama K., Tsujikawa K., Inoue H., Biol. Pharm. Bull., 41, 106-114 (2018)

7) Goromaru T., Kawauchi T., Katashima M., Matsuura H., Yoshimura N., Sameshima T., Miyawaki T., Jpn. J. Anesthesiol., 35, 35-39 (1986) .

8) Kanamori T., Togawa Iwata Y., Segawa H., Yamamuro T., Kuwayama K., Tsujikawa K., Inoue H., Forensic Toxicol., 36, 467-475 (2018).

9) Kanebratt K. P., Andersson T. B., Drug Metab. Dispos., 36, 14444-14452 (2008).

10) Yamasaki C., Kataoka M., Kato Y., Kakuni M., Usuda S., Ohzone Y., Matsuda S., Adachi Y., Ninomiya S., Itamoto T., Asahara T., Yoshizato K., Tateno C., Drug Metab. Pharmacokinet., 25, 539-550 (2010). 